\title{
Rendición de Cuentas
}

\author{
Por Monseñor JOSE DAMMERT BELLIDO, \\ Catedrático Títular de Derecho Romano \\ Director de la Sindicatura Eclesiástica
}

El Código de Derecho Canónico, en diversos cánones, dispone que el Ordinario del lugar, debe vigilar la administración de los bienes eclesiásticas; $\mathrm{y}$ que los administradores deben presentarle anualmente las cuentas, para su aprobación.

El canon 1525, expresamente dispone: "Reprobada la costumbre contraria, los administradores, tanto eclesiásticos como seglares, de cualquier iglesia, incluso la Catedral, o de lugares piadosos, canónicamente erigidos, - de Cofradías, están obligados a rendir todos los años, cuenta de su administración al Ordinario del lugar" (par. $1^{\circ}$ ).

El mismo canon no admite ninguna excepción: "Si por derecho particular tienen que rendir cuenta a otros designados al efecto, en ese caso, se admitirá también, juntamente con ellos, al Ordinario del lugar o a su Delegado, de tal forma que la aprobación de las cuentas hechas de otro modo, de nada les sirve a los administradores" (par. 2c).

Esta última disposición comprende todos los casos, en que sea por estatuto particular o por la ley civil, se deba rendir cuentas a otra autoridad. Por ejemplo, las fundaciones eclesiósticas que también poseen carócter civil, además de someter sus cuentas al Ministerio Fiscal (art. 67 del C. C. peruano; y art. $4^{\circ}$ de la ley 8728 , sobre fundaciones), están obligadas a presentarlas al Ordinario del lugar, pues faltando este requisito no les valdría de nada. Igualmente debe decirse de las cuentas de las Cofradías, Archicofradías y Congregaciones, cuyos bienes son administrados por la Beneficencia Pública, de acuerdo con la ley peruana de 2 de Noviembre de 1889.

OBLIGADOS A RENDIR CUENTAS:-Según el canon citado, deben rendir cuentas todos los administradores, tanto seglares (ver también cn. 1521, par. $2^{\circ}$ ), como eclesiósticos. Otros cánones indican expresamente $a$ algunos de ellos.

Cualquier Iglesia, incluyendo la Catedral, lugares píos, y Cofradías (cn. 1525, par. 19);

La Superiora de cualquier Monasterio de monjas, aunque sea exento (cn. 535 , par. $1^{9}$ ); 
Las asociaciones de fieles en general, erigidas legítimamente (cn. 691, par. 19), esto es, Cofradías, Pías uniones, Acción Católica, etc.

Las iglesias, tanto de seculares, como de religiosos, por las misas recibidas (cn. 843 , par. $2^{\circ}$ );

El Párroco, el misionero, o Rector de una iglesia secular, ya sea éste secular, ya religioso ( $\mathrm{cn}$. 1182, par. $3^{\circ}$ );

Los piadosos institutos, aún cucndo se les haya eximido de la jurisdicción y visita del Ordinario (cn. 1492, par. 1\%), y no se aceptará la fundación, si el fundador pretende que los administradores no queden obligados a rendir cuentas al Ordinario del lugar" (par. 2\%);

Las piadosas fundaciones, por las cargas perpetuas y temporales, con sus respectivas limosnas (cn. 535, par. 1\%).

TIENPO DE RENDICION DE CUENTAS.-La rendición debe ser anual, según establece el canon 1525, par. $1^{\circ}$, para todos los administradores, y en particular, los monasterios de monjas (cn. 535, par. $1^{\circ}$ ), y libros de colecturias de misas (cn. 843).

Por constitución N 120 del XIV Sínodo Arquidiocesano de Lima, "las cuentas del Ecónomo del Seminario de Santo Toribio, se cerrarán el 31 de Marzo. Las del V Cabildo Metropolitano, parroquias, capellanías, obras pías y monasterios, el 31 de Diciembre" (n. 2). ."Los administradores presentarán sus cuentas, dentro del trimestre siguiente a la clausura del año económico" (n. 3). Los que no lo hagan, sufrirán a partir del mes siguiente una multa equivalente a la mitad de su haber mensual, multa que se repetirá todos los meses, hasta que presenten sus cuentas, y si, a pesar de eso, no se presentaran las cuentas, serón removidos" (ibidem).

CUENTAS QUE DEBEN SER PRESENTADAS.-Los administradores deben dar cuenta de su administración (cn. 1525, n. 1); para las asociaciones de fieles, ver cn. 691, par. 1ㅜ, beneficios (cn. 1478); obras pías (cn. 1492); monasterios de monjas, aún exentos (cn. 535 , par. $3^{\circ}$, n. 1);

Las casas religiosas de derecho diocesano de sus cuentas económicas (ídem, par. $3^{\circ}$, n. l);

El Superior o Superiora de una casa de congregacićn religiosa tratándose de fondos que han sido dados o legados a la casa para el culto divino, o para obras de beneficencia en aquel mismo lugar (idem $\mathrm{n}$. cfr. can 533 , par. $1^{\circ}$, n. 3 );

Cualquier religioso, aunque pertenezca a una Orden regular, si el dinero fué dado para una parroquia o misión, o a los religiosos en beneficio de las mismas (ídem, cfr. cn. 533, par. 2, n. 4);

Los bienes que constituyen las dotes en las congregaciones religiosas de mujeres (cn. 535, par. $2^{\text {') }}$;

Los libros en que se anotan el número, intención, limosna y celebra. ción de las misas recibidas (cn. 843, par. 19), y las cargas perpetuas y temporales, con sus respectivas limosnas (cn. 1549, par. $2^{\circ}$ );

Los donativos hechos en beneficio de la parroquia o de la iglesia secular (cn. 1182, par. $2^{\circ}$ y $3^{\circ}$ ); los donativos y limosnas recibidos por las asociaciones de fieles (cn. 691, par. 5). 
REVISION DE CUENTAS.-Los revisores de cuentas serón nombrados por el Ordinario (XIV Sínodo const. 35 n. 1), y durarón un año en su cargo, pudiendo ser reelegidos (n. 2).

Por disposición arzobispal última se ha centralizado en la Sindicatura Eclesiástica, todo lo que concieme a la revisión de cuentas.

La forma cómo deben ser presentadas las cuentas, estó determinada por el Sínodo XIV (const. $120 \mathrm{nn} .4$ a ll).

El procedimiento para la revisión de cuentas, se fija en la constitución $35 \mathrm{nn} .3 \mathrm{al} 8$.

El "Tribunal de Cuentas" fué establecido por la Constitución 36, en la que fija su pauta de acción.

Los derechos de aprobación de cuentas que percibe la Curia Arzobispal, son de S/. $10.00 \mathrm{y} \mathrm{S} / .20 .00$, según que las cuentas sean inferiores o superiores a la suma de diez mil soles oro (Äsamblea Episcopal de 1948, n. 31).

La gratificación que percibe el Revisor estó señalada en la Const. n. 35 n. 9 del XIV Sínodo.

DESAPROBACION DE CUENTAS.-"Si el Ordinario no aprueba la administración (de lós monasterios̀ de monjas), puede aplicar los remedios oportunos, aun removiendo del cargo, si el casō lo pide, a la ecónoma o a los demás administradores" (cn. 535, par. 19, n. 2).

"El beneficiado, si fuese negligente o de otro modo se hiciere culpable, debe resarcir los daños causados al beneficio, y ha de ser compelido a ello por el Ordinario del lugar; y si es Párroco, puede ser removido de la parroquia" (cn. 1476 par. 2\%). 


\section{Notas}

\section{LO QUE PRUEBAN LAS PARTIDAS PARROQUIALES}

"Las partidas de bautismo, confirmación, ordenación, profesión religiosa, matrimonio y defunción, que se conservan en los archivos de la Curic, parroquia y religión, y los atestados escritos sacados por los párrocos, Ordinarios, o notarios eclesiásticos, así como las copias auténticas de las mismas son documentos públicos eclesiásticos (cn. 1813 par. In. 4).

Los documentos públicos hacen fe acerca de aquello que en los mismos, directa y principalmente, se afirma (cn. 1816).

"Directamente se afirma el hecho que la persona pública ha percibido con sus sentidos, no cualquier otra realidad distinta que el hecho presupone. La fuerza probatoria del documento público se limita además a lo que en el principal, no incidentalmente, se intenta demostrar". (Anotación del Cód. Iur. Can. bilingüe).

Entonces, la partida de Bautismo sólo hace fe acerca del "hecho del bautismo", que es lo único que directa y principalmente afirma. Tanto que la legitimidad de los hijos no se prueba con las partidas de bautismo, los cánones 1114 y 1115 dicen muy claramente cómo se demuestra.

Igualmente la S. R. Rota ha declarado que el pórroco en el libro de matrimonios, hace fe sobre el mismo acto o celebración del matrimonio, pero no acerca de otras cosas concernientes al oficio del párroco, ni siquiera acerca de la validez del mismo matrimonio que debe probarse por otros medios ("Decisones seu sententiae XIX, 70, 14 de marzo 1927).

Al iniciarse los trómites para la inscripción y rectificación de partidas, debe recordarse a los demandantes lo anteriormente expuesto para evitar que se recurra a estos procedimientos para probar cosas diferentes, como entroncamientos, parentescos, legitimidad, etc. $\bar{Y}$ tal vez sería oportuno que al dictar el Juez Eclesióstico la resolución respectiva, cumpliałas las normas procesales seńaladas por los cns. 779, 797, y el Apéndice n. 17-1 del VIII Concilio Limense, indique en ella qqủe únicamente se quiere probar el hecho del bautismo o del matrimonio.

J. D. B. 